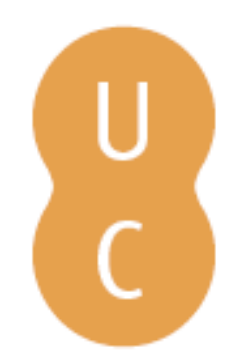

\title{
nombalina
}

\section{Bibliometric study of fires in tropical rain forests}

Autor(es): $\quad \begin{array}{ll}\text { Juárez-Orozco, Sonia; Siebe-Grabach, C; Fernández y Fernández, D; } \\ \text { Michán, L }\end{array}$

Publicado por: Imprensa da Universidade de Coimbra

URL

persistente: URI:http://hdl.handle.net/10316.2/34161

Accessed : $\quad$ 26-Apr-2023 13:54:38

A navegação consulta e descarregamento dos títulos inseridos nas Bibliotecas Digitais UC Digitalis, UC Pombalina e UC Impactum, pressupõem a aceitação plena e sem reservas dos Termos e Condições de Uso destas Bibliotecas Digitais, disponíveis em https://digitalis.uc.pt/pt-pt/termos.

Conforme exposto nos referidos Termos e Condições de Uso, o descarregamento de títulos de acesso restrito requer uma licença válida de autorização devendo o utilizador aceder ao(s) documento(s) a partir de um endereço de IP da instituição detentora da supramencionada licença.

Ao utilizador é apenas permitido o descarregamento para uso pessoal, pelo que o emprego do(s) título(s) descarregado(s) para outro fim, designadamente comercial, carece de autorização do respetivo autor ou editor da obra.

Na medida em que todas as obras da UC Digitalis se encontram protegidas pelo Código do Direito de Autor e Direitos Conexos e demais legislação aplicável, toda a cópia, parcial ou total, deste documento, nos casos em que é legalmente admitida, deverá conter ou fazer-se acompanhar por este aviso.

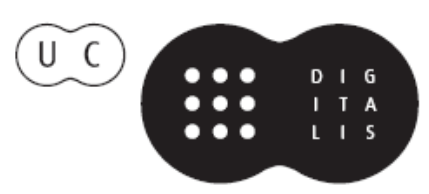




\section{ADVANCES IN}

Forest Fire

\section{RESEARCH}

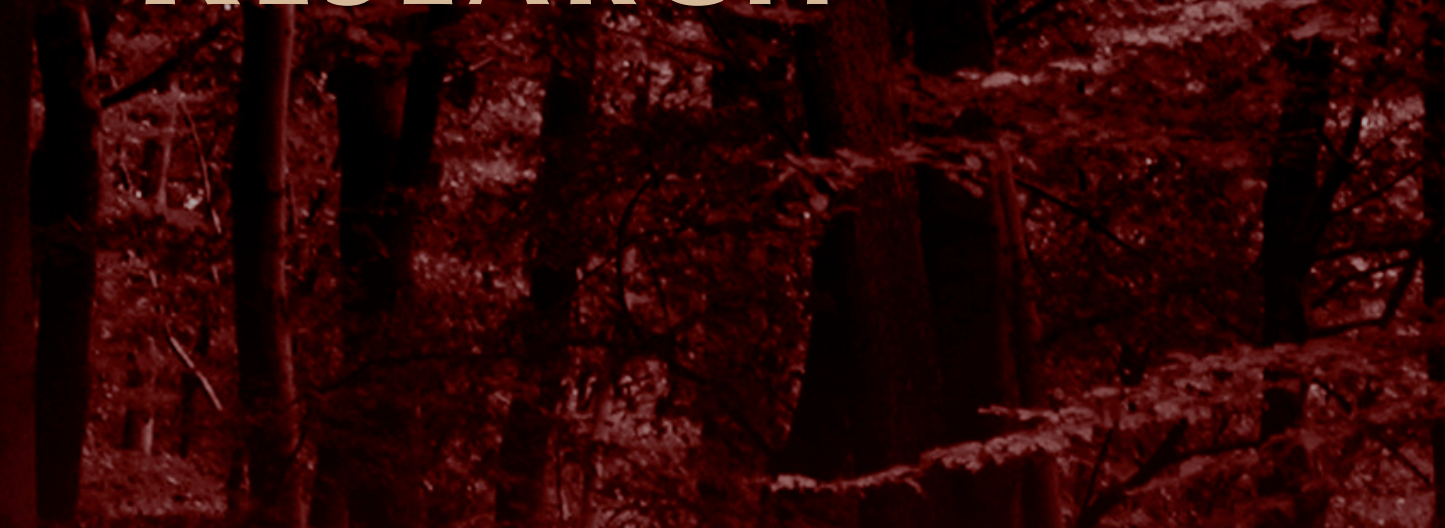

\section{DOMINGOS XAVIER VIEGAS}

\section{EDITOR}




\title{
Bibliometric study of fires in tropical rain forests
}

\author{
Sonia Juárez-Orozco a , Siebe-Grabach C ${ }^{\mathrm{b}}$, Fernández y Fernández D and Michán L ${ }^{\mathrm{c}}$ \\ ${ }^{a, b}$ Instituto de Geología, Universidad Nacional Autónoma de México, Mexico City, E-mail: \\ soni@ciencias.unam.mx,siebe@unam.mx \\ ${ }^{c}$ Laboratorio de Cienciometría, Información e Informática Biológica (CIIB), Departamento de \\ Biología Comparada, Facultad de Ciencias, UNAM, laylamichan@ciencias.unam.mx, \\ danielafyf@gmail.com
}

\begin{abstract}
Bibliometrics allows to analyze on behalf of literature searches the existing knowledge around a specific topic and identify tendencies in its development. Tropical forests are characterized naturally by a low regime of fires. However human activities have dramatically changed this phenomenon. Since tropical rain forests are a hot spot of world's diversity, we conducted a bibliometric study of occurrence and effects of fires in tropical rain-forests. The aim of this work is to identify the main tendencies in biological literature about this subject, diagnose knowledge areas with a poor development and to define the geographic location of the performed studies and their methodological approach. This analysis will allow to identify the main gaps in the research of fires in tropical rain forests and contribute to direction the following research projects. We retrieved more than 2000 documents of indexed journals from the following bibliographic databases: Web of Science, Scopus, Science Direct, Biosis and Zoological abstracts. We selected the papers of words related with forest fires and tropical rain forests by an advanced search using logic and boolean operators. We considered for this study the fields: the document title, authors, adscription institution, publication year, journal name,

Keywords and descriptors, country, knowledge area and abstract. With this information we designed and normalized the database. Then, we considered all the papers focused on the study of fires in tropical forests and we classified other works that not specifically worked on fires but mention it as an important element of their studies. We did this by looking for the words "fire" and "tropical forest" in the

Keywords and abstracts. Then we analysed the documents by their geographic location and by the field of knowledge. We found an increasing interest in this topic in the scientific community since early 1950 to the present. The journals with more works in the theme were Forest ecology and management and Biotropica. We consider that this bibliometric review will help to the decisions making.
\end{abstract}

Keywords: publication temporality, authors, indexed journals, knowledge fields, study site locations, bibliometrical studies

\section{Introduction}

The generation of new information has impacted scientific work since the appearance of computers and the development of software. This technology allows to analyze on behalf of literature searches the existing knowledge on a specific topic and to identify tendencies in its development (MichánAguirre and Muñóz-Velasco 2013). It known as bibliometrics, which is a set of methods to quantitatively analyze academic literature (Wilson 1999; Hull et al. 2008).

Forest fires are related with global warming, decrease of forested area, loss of biodiversity and an increase of erosion. There are a lot of ecological parameters that change after a forest fire like vegetation cover, density, structure, composition, diversity and productivity. Therefore, forest fires are recognized as an interesting topic among foresters. Tropical forests are characterized naturally by a low fire regime (Bowman et al. 2011). However, in the last decades forest fires have become increasing events in these fragile ecosystems (Cochrane 2001). This relationship has been widely explored in temperate and mediterranean forests where plants have adapted to fire. 
Agricultural and ranching activities are highly associated with forest fires. It is known that swidden cultivation is still an important agricultural practice, especially in areas where intensive agriculture is not possible (Van Vliet et al. 2012). However, fire plays also an important role in many parts of the world where it induces land uses change to for example cattle production or the cultivation of biofuel plants.

Bibliometric studies have been used for example to understand the direction of several ecologic phenomena such as changes in diversity and impact of conservation strategies (Song and Zhao 2013), by studying the information process and its change over time (Young and Wolf 2006; Stork and Astrin 2014).

According to FAO (1993) tropical forests are located in tropical areas within different biogeographic origins. They have a high plant and animal richness and show a wide range in composition, structure, functionality and productivity. The evergreen tropical rain forests are located in regions where the total annual rainfall is greater than $2500 \mathrm{~mm}$ and the dry season is either short or inexistent.

Since tropical rain forests are a hot spot of world's diversity and lately have been increasingly affected by fire to induce land use change, the objective of this study is to know the state of the art of tropical rain forest fire research. In particular, we wanted to determine which countries that possess tropical rain forest have reported fires and how this subject is addressed by the scientific community. It is important to detect the causes of unusual fire regime in tropical forest and which are the expected changes. The aim of this work is to identify the main tendencies in biological literature about this subject, detect the knowledge gaps and to define the geographic location of the performed studies and their methodological approaches.

\section{Methods}

We retrieved articles of indexed journals published until April 2013 from the following bibliographic databases: Web of Science, Scopus, Science Direct, Biosis and Zoological abstracts. We selected the papers by an advanced search (filtered) using the logic and boolean operators AND, OR, NOT, ?, * and "'" that included words related with forest fires and tropical rain forests (Figure 1). We considered for this study the following fields: (1) the document's title, (2) authors, (3) adscription institution, (4) publication year, (5) journal name, (6) keywords and descriptors, (7) country, (8) discipline and (9) abstract. With this information we constructed a database and normalized records eliminating all the papers that were within the scope of our objectives and completed and annotated all the nine fields. Pre-processing included duplicate deletion and pertinence selection. In addition, we selected the documents that mention in their title the word soil, as it is an important compartment that changes after a forest fire and we re-classified the soil types according to the WRB soil classification (IUSS, 2007). Then, we considered all the papers focused on the study of fires in tropical forests and we classified other works that not specifically worked on fires but mention it as an important element in their studies. We did this by looking for the words "fire" and "tropical forest" in the keywords and abstracts and all of their synonyms and homonyms which were defined utilizing the Cab Abstracts thesaurus. The results of the search were restricted to only articles from environmental disciplines. The whole process of the method is resumed in Figure 2. 
TITLE-ABS-KEY ("Tropical rain forest*" OR "Tropical timber*" OR "Tropics" OR "Tropical countr*" OR "Tropical climat*" OR "Tropical America" OR "tropical crop*" OR "Tropical burn weed*" OR "Tropical forest*" OR "Tropical dry forest*" OR "Tropical seasonal forest*" OR "Semi-evergreen seasonal forest*" OR "Deciduous seasonal forests" OR "Equatorial forest*" OR "Rain forest*" OR "Tropical rain forest*" OR "Tropical timber*" OR "Tropics" OR "Tropical countr*" OR "Tropical climat*" OR "Tropical America") AND TITLE-ABS-KEY ("Fire regime*" OR" Managed wild land fire*" OR "Prescribed natural fire*" OR "Prescribed fire*" OR "Natural fire*" OR "Wild fire*" OR "Wildfire*" OR "Let burn" OR "Manager-ignited fire*" OR "Wild land fire*" OR "Burn*" OR "Ignition*" OR "Shifting agriculture*" OR "Shifting cultivation*" OR "Hot spot*" OR "Indian fire*" OR "Slash-and-burn*" OR "Fire*" OR "Slash and burn*" OR "Ash*" OR "Fuel*" OR "Fire trend*" OR "Fire *adapted" OR "fire-*" OR "Fire regime*" OR "Managed wild land fire*" OR "Prescribed natural fire*" OR "Prescribed fire*" OR "Natural fire*" OR "Wild fire*" OR "Wildfire*"OR "fire history" OR "fire trend*")

Figure 1. Terms and algorithms used in the advanced search

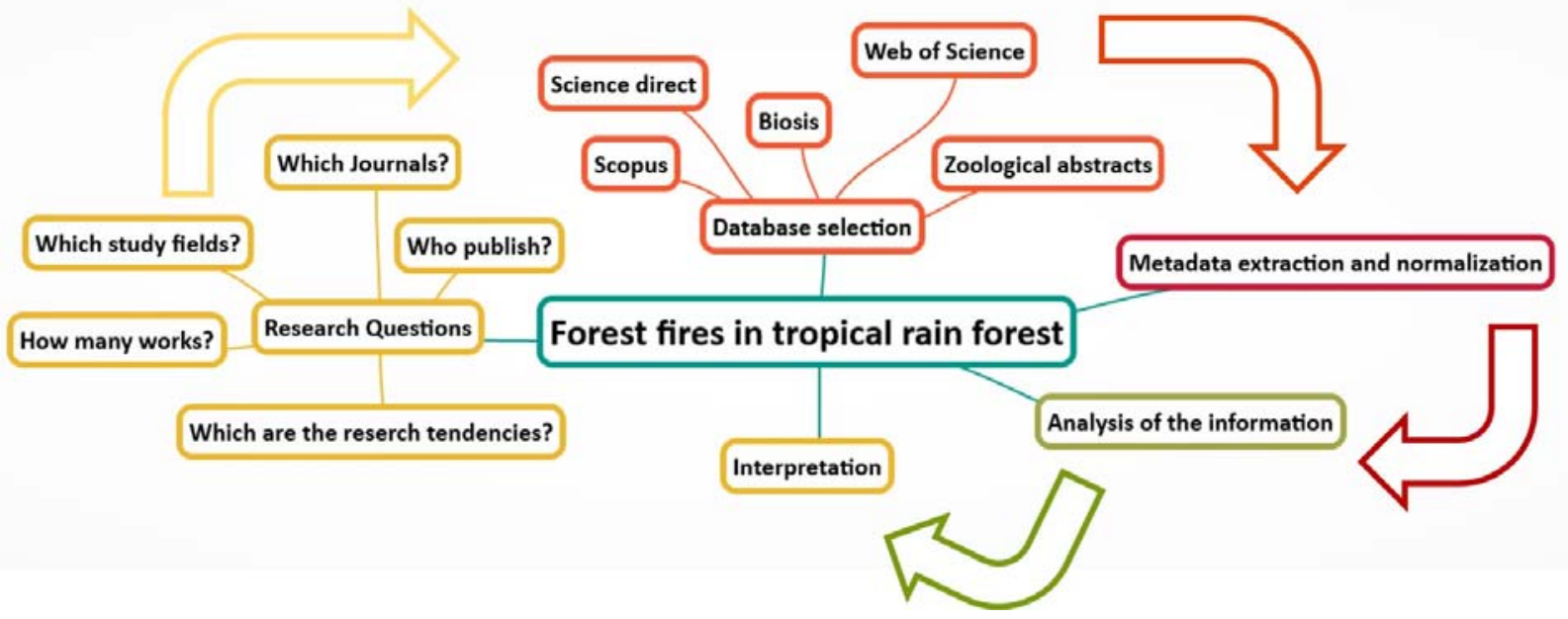

Figure 2. Stages of the documental research

\subsection{Statistical analysis}

Absolute and relative frequencies of the above fields were obtained. We analysed the documents by their geographic location and by field of knowledge. We also calculated the frequency of words appearing in the title and keywords of the documents to see which are the main fields addressed by the scientific community. We conducted a keyword analysis, by calculating the probability to find one word by inserting another one.

\section{Results}

In total we recorded 2000 publications. The following results belong to the analysis of these records. Reports on fires in tropical rain forests started in 1960. From the beginning of the 1980's articles on fire in tropical rain forests have been growing steadily. This growth pattern is shown for papers that either just report a forest fire in a tropical forest $(\mathrm{N}=1982)$ or focus specifically on this phenomenon $(\mathrm{N}=498)$ (Figure 3).

Research about tropical rainforest fires was conducted in 42 countries. Most of these studies have been done in the American continent (49.34 \%), followed by Asia (26.54\%), Australia (15.79\%) and Africa $(8.33 \%)$. The most productive countries of each region were Brazil (141), Venezuela (18) and México (16) for America; Indonesia (55), India (25) and Malaysia (23) for Asia; Australia (63) for Australia 
and Cameroon (10) and Madagascar (7) for Africa. However, the distribution in the number of these studies does not reveal which countries have more forest fires in their corresponding tropical rainforests. Tropical rain forest are decreasing their area due to deforestation and in many cases fire is a tool that facilitates the advance of agriculture. Figure 4 shows the remains of tropical forests distributed around the world. The Amazon, for example is the greatest area covered with rainforest in the world, and also one of the regions in which forest fires are most studied. Although, this is not related with the real number of forest fires in this area, but rather is related with the number of investigations conducted in these areas. These data show that rather few studies exist on fire studies in these forests, in which plants have not adapted to cope and to recover after a fire and in consequence allows exotic plants to disseminate.

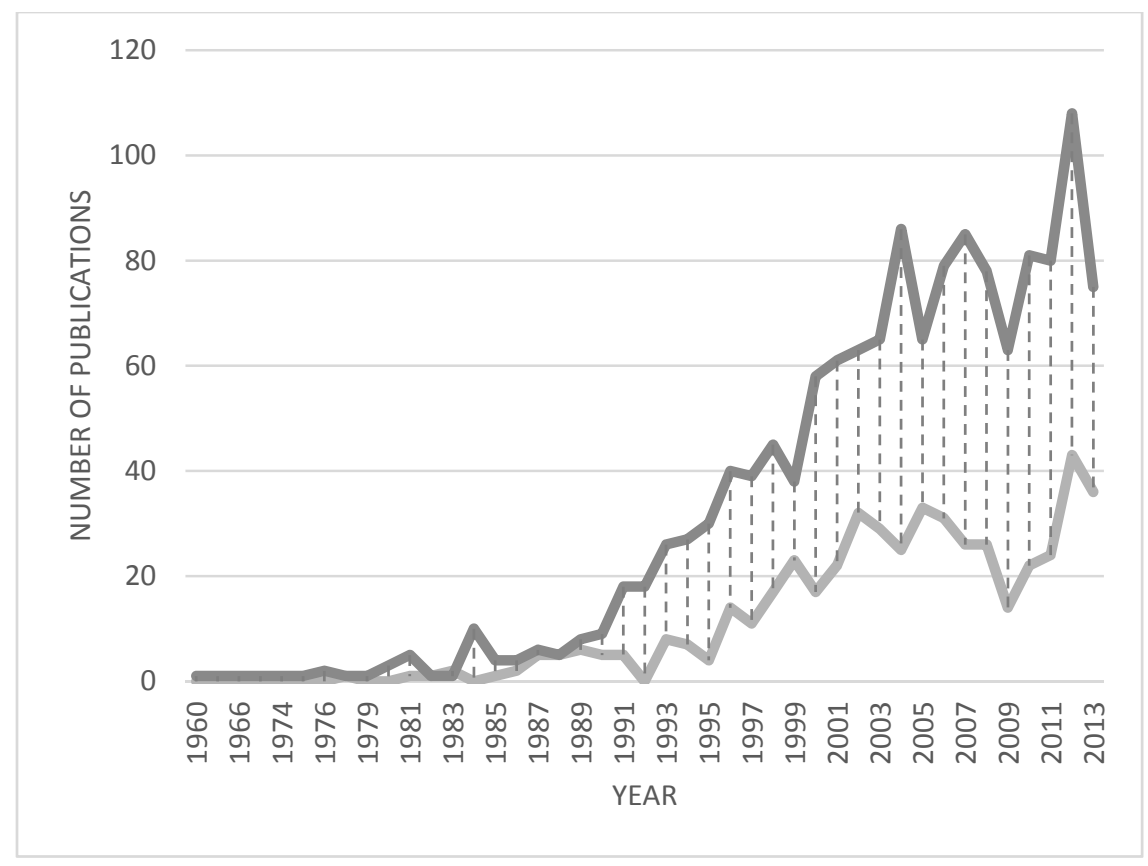

Figure 3. Temporal variation in the number of publications. Lines in dark grey denote studies in which forest fires are mentioned $(N=1982)$, and lines in light grey represent publications focused on tropical rainforest fires until April $2013(N=498)$. 


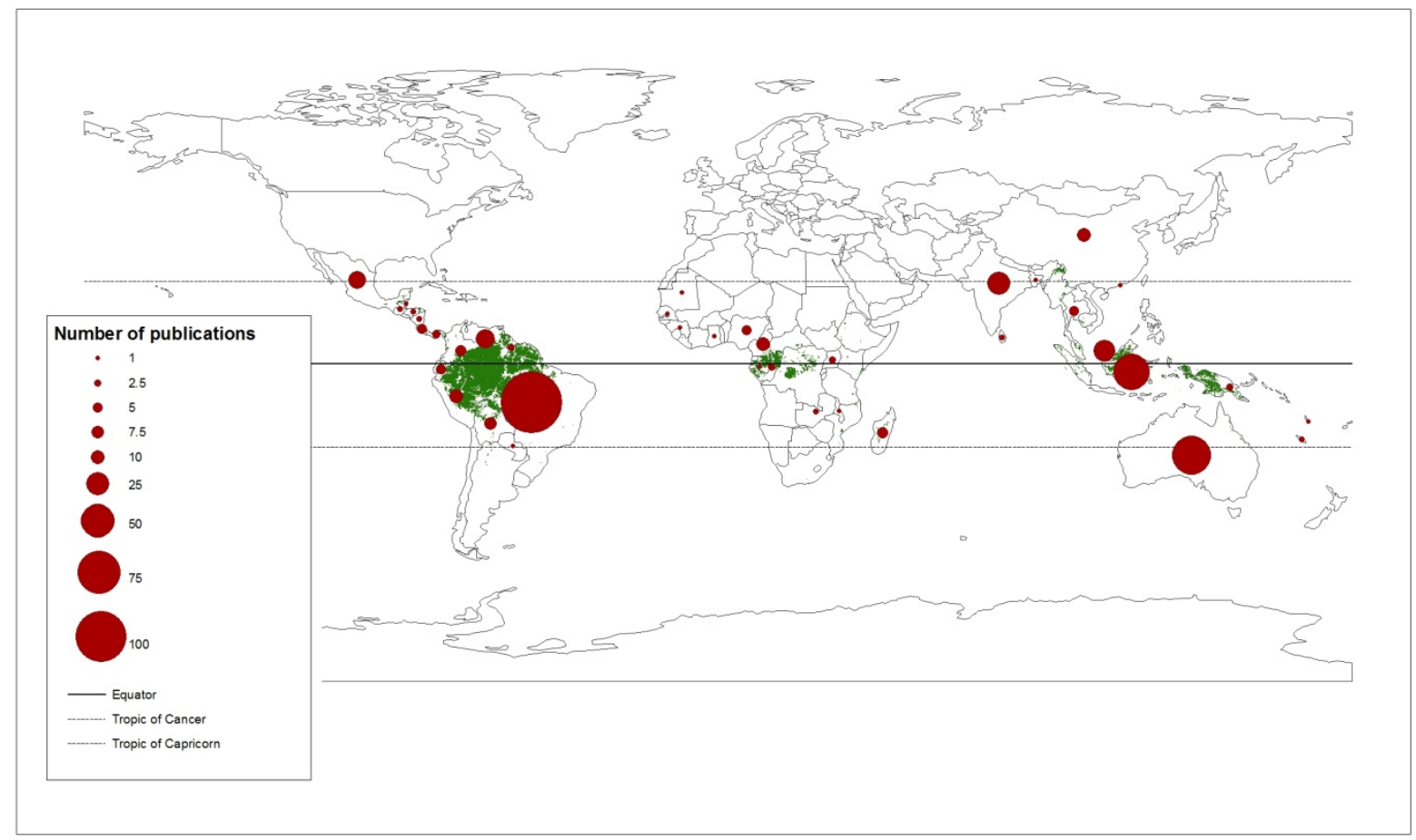

Figure 4. Spatial distribution of publications at global scale focused on fires in tropical rainforests. Green areas represent the principal remains of tropical rainforests (Wildlife Conservation Society). Red dots represent the number of publications.

The journals with most studies dealing with the topic were Forest Ecology and Management, Biotropica and the International Journal of Remote Sensing with 24, 20, 18 and 17 publications, respectively. Terms like slash and burn agriculture are frequent. The papers were published in 192 international journals. We identified ten journals that form together $31.53 \%$ of the published scientific articles related with fires in tropical forests. The contribution of each journal was: Forest Ecology and Management (4.82\%), Biotropica (4.02\%), International Journal of Remote Sensing (3.61 \%), Journal of Tropical Ecology (3.61 \%), Remote Sensing of Environment (3.21\%), Biodiversity and Conservation (2.81\%), Agriculture, Ecosystems and Environment (2.61\%), Ecological Applications (2.41\%), Journal of Biogeography (2.41\%) and Austral Ecology (2.21\%) (Figure 5).

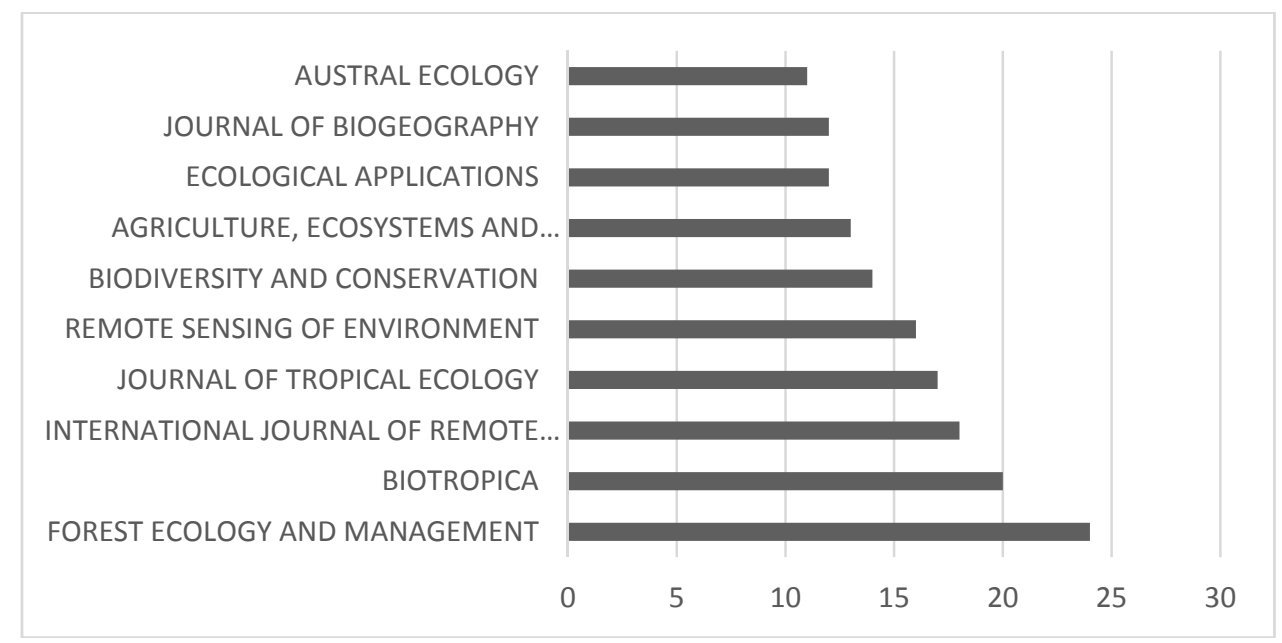

Figure 5. Main journals and the number of publications related with fires in tropical rain forests. $N=498$ articles. 
There were 5195 terms in our keyword analysis. These terms provide information on the main interests in the scientific community related with fires in tropical rainforests. As expected, fire, forest, tropic, burn and shifting are the words that appear most in the literacy, since these were the terms selected in the advanced search. Other terms are cultivation, effect, use, Amazon and change, which were the five most repeated terms among the key words in the published documents. The key words cultivation and use are related with human activities such as agricultural practices in which fire is used for several purposes. On the other hand, the term effect shows that the effect of fire is one of the main research topics. Apparently, rainforest are unnaturally burned with more frequency than expected in nature. It is of particular interest that Amazon is one of the most frequent words since it is the largest area covered with tropical forests and also the area where more scientific articles are produced. Table 1 shows the most used terms among which regions or countries can be identified, in which the causes of fire are being studied around the world. The majority of documents are associated with ecological disciplines followed by soil science, agronomy and remote sensing (Figure 7).

Table 2. Stemmed key word frequency $(N=498)$

\begin{tabular}{lcclcclcc}
\hline Global & freq. & Global \% & Global & freq. & Global \% & Global & freq. & Global \% \\
\hline Fire & 308 & 5.929 & brazilian & 29 & 0.558 & northern & 18 & 0.346 \\
Forest & 244 & 4.697 & speci & 29 & 0.558 & recover & 18 & 0.346 \\
Tropic & 127 & 2.445 & amazonian & 28 & 0.539 & savanna & 18 & 0.346 \\
Burn & 99 & 1.906 & australia & 27 & 0.52 & spatial & 18 & 0.346 \\
Cultiv & 69 & 1.328 & system & 27 & 0.52 & borneo & 17 & 0.327 \\
Shift & 67 & 1.29 & rainforest & 26 & 0.5 & composit & 17 & 0.327 \\
Effect & 56 & 1.078 & area & 25 & 0.481 & landscap & 17 & 0.327 \\
Use & 55 & 1.059 & divers & 25 & 0.481 & regim & 17 & 0.327 \\
Amazon & 47 & 0.905 & eastern & 23 & 0.443 & studi & 17 & 0.327 \\
Slash & 45 & 0.866 & amazonia & 22 & 0.423 & swidden & 17 & 0.327 \\
Chang & 40 & 0.77 & data & 22 & 0.423 & brazil & 16 & 0.308 \\
Rain & 40 & 0.77 & respons & 22 & 0.423 & central & 16 & 0.308 \\
Biomass & 39 & 0.751 & log & 21 & 0.404 & fallow & 16 & 0.308 \\
tree & 38 & 0.731 & communiti & 20 & 0.385 & nutrient & 16 & 0.308 \\
veget & 34 & 0.654 & southern & 20 & 0.385 & region & 16 & 0.308 \\
agricultur & 33 & 0.635 & year & 20 & 0.385 & wildfir & 16 & 0.308 \\
dynam & 32 & 0.616 & deforest & 19 & 0.366 & east & 15 & 0.289 \\
impact & 32 & 0.616 & indonesia & 19 & 0.366 & global & 15 & 0.289 \\
soil & 32 & 0.616 & manag & 19 & 0.366 & analysi & 14 & 0.269 \\
land & 31 & 0.597 & structur & 19 & 0.366 & bird & 14 & 0.269 \\
\hline
\end{tabular}




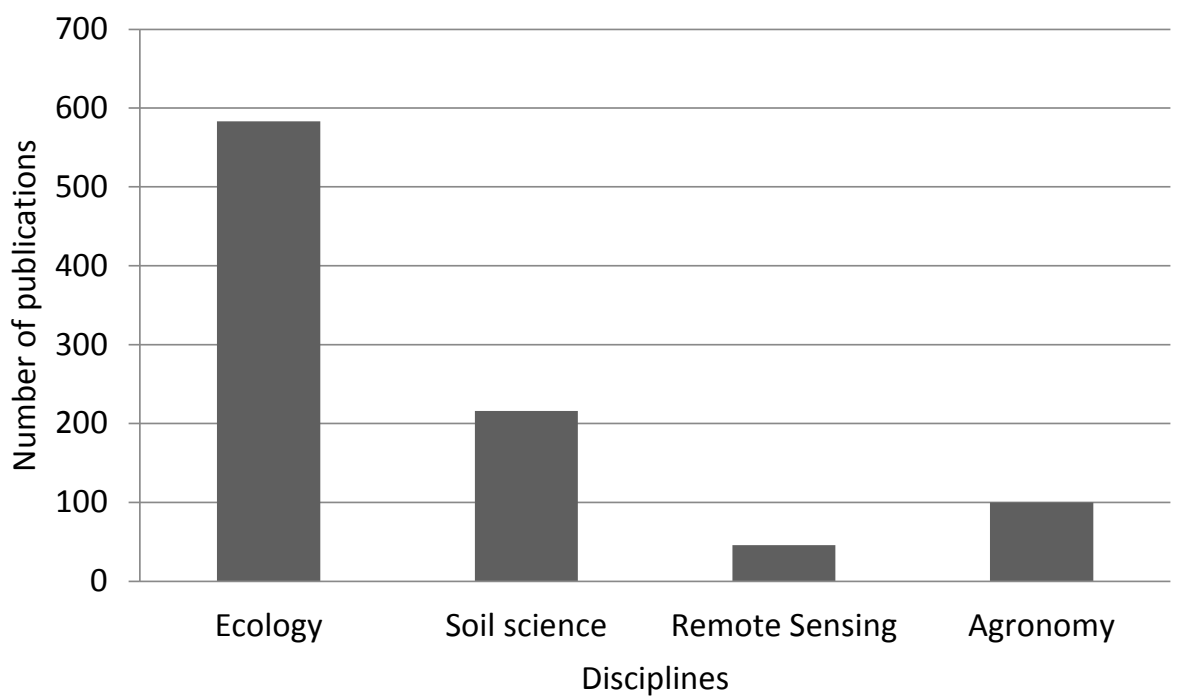

Figure 7. Disciplines that study forest fires in tropical rainforests

Only 32 of the reviewed articles were focused on the changes occurring in soil after a fire in tropical rainforests. From these studies, 15 did not report the kind of soil present in the study area. The principal topics taken into account were physicochemical changes in the soils after a fire, but also the effects of fires on macro and microbiota. In soil the most commonly reported changes are the soil $\mathrm{pH}$, organic matter content and exchangeable cations like potassium and calcium, as well as changes in nitrate and phosphorus contents. These properties are important for farmers to assure a good harvest. Their loss over time leads to soil degradation.

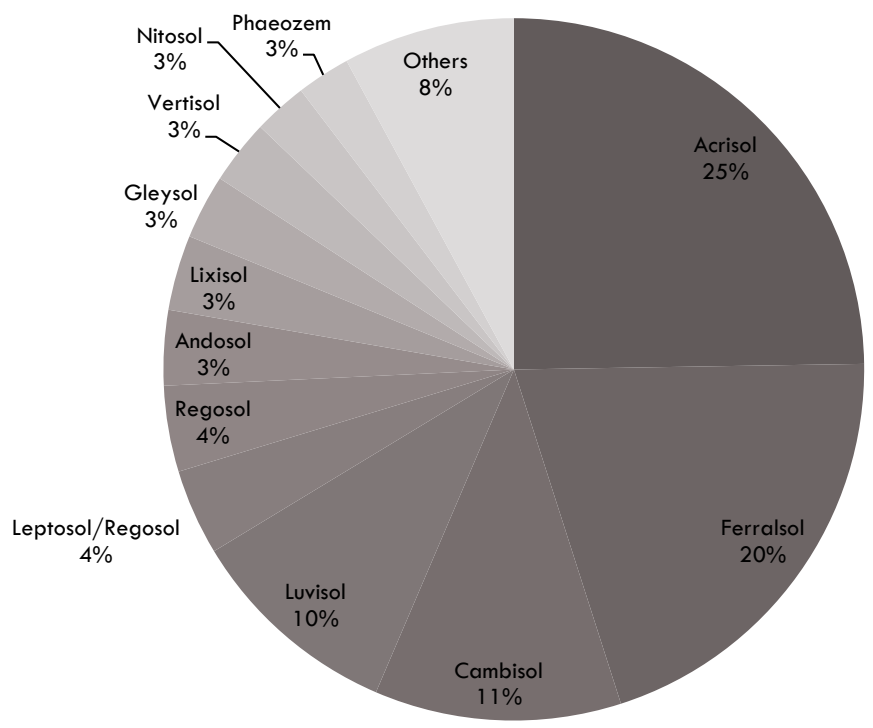

Figure 7. Main soil reference groups in which studies on fires in tropical rainforests have been done. 


\section{Discussion}

Forest fires represent a threat for the relicts of tropical forests around the world. Natural fires in these ecosystems are rarely reported. Instead, publications on forest fires are increasing. Fires on tropical rainforests appear to be more frequent, intense and extended over the time (Pyne 1995; Cochrane 2002). Mouillot and Field (2005) estimate that in the 1990's alone $54 \mathrm{Mha} \mathrm{yr}^{-1}$ of tropical rainforests were affected by fire. Some consequences on the environment are gas emissions, which between 1997 and 1998 represented approximately $40 \%$ of the emissions produced by burning of fossil fuel (Cochrane 2003). It is necessary to know the real numbers of fires occurring in the tropical rain forest over the world and which is the extent of these events. These studies ought to reveal the causes, which can be a high rate of land conversion to agriculture or pasture, proximity to roads and rural roads, population density or climatological causes which include long periods of dryness related to the climatic global changes. Taking in account a mesoscale approach (mesoscales $\gamma$ and $\beta, 2-20,20-200$ $\mathrm{km}$, respectively; Stull 1988), relatively few remote sensing studies were focused in detection, burned area calculation and land use change.

Spatially, forest fires are reported worldwide. According with information of the World Bank (2014) most of the countries in the tropics have a high rural population and low GDP per capita, excepting Australia. Conversely, continents like Africa show less reports of fires in their forest than more developed regions as Australia. In the case of America, there is a vast production of articles in the Amazon region, such as Brazil, Venezuela and others. Nevertheless, there is a smaller productivity of articles in Central America. In Asia the largest number of articles have been published in Indonesia, India and Malaysia.

The discipline of most research studies was ecology. Among the most studied ecological factors were: diversity, structure, recovery and composition. These variables reflect that most of the ecological studies are focused on the community level, but also some investigations deal with landscape and ecosystem scale. Biomass, for example is one of the most important elements in ecology, but also in management and prevention of fires. In the case of remote sensing the principal interests were focused in detection of forest, the calculation of the burned area and on land use change. Therefore biomass should be included in the remote sensing studies to make models with an ecosystem approach that explain a huge part of the fire dynamic and improve the fire management and prevention programs.

Agriculture activities usually are the origin of fire and soil properties change are a consequence of these activities which also are related with crop productivity. A deep bibliometric study can help us to understand how and which changes in soil properties, after fires and over time, are generalizable. We need to synthetize and make deep bibliometric studies to relate all the ecosystem properties studied until now to bigger scales. This initial bibliometric study is a first step in a research topic to understand how bibliometric studies in different fields, as in other cases have shown to understand different phenomena and how they have helped on making decisions about different topics like conservation of biodiversity (Stork and Astrin 2014) or which are the ecological consequences of land use change (Hasanagas et al. 2010). Bibliometric studies in different fields have allowed to understand complex phenomena and in some cases they can help to take decisions (Hasanagas et al. 2010). Finally, we consider that this bibliometric review will help to the decisions making helping us to understand the relevance of the different scale approaches and the gaps in fire ecology to evaluate both the effects of climatic change, the real relevance of shifting cultivation and other anthropogenic activities on fire dynamics, its consequences, management and prevention.

\section{Acknowledgements}

I thank PAPPIT project IN221613-3, Capacidad de sosten y resiliencia de unidades geoecológicas manejadas como jardines forestales en las tierras bajas mayas. 


\section{References}

Bowman DM, Balch J, Artaxo P, Bond WJ, Cochrane MA, D’Antonio CM, DeFries R, Johnston FH, Keeley JE, Krawchuk MA, others (2011) The human dimension of fire regimes on Earth. Journal of biogeography 38(12), 2223-2236.

Cochrane MA (2001) In the line of Fire Understanding the Impacts of Tropical Forest Fires. Environment: Science and Policy for Sustainable Development 43(8), 28-38.

Cochrane MA (2002) Spreading like wildfire: tropical forest fires in Latin America and the Caribbean: prevention, assessment and early warming.

Cochrane MA (2003) Fire science for rainforests. Nature 421(6926), 913-919.

FAO. 1993. The Challenge of Sustainable Forest Management. Chapter 2: The world's forests. Rome. http://www.fao.org/docrep/t0829e/T0829E04.htm\#Tropical forests

Hasanagas ND, Styliadis AD, Papadopoulou E (2010) Environmental Policy $\backslash \&$ Science Management: Using a scientometric-specific GIS for e-learning purposes. International Journal of Computers, Communications and Control 5(2), .

Hull D, Pettifer SR, Kell DB (2008) Defrosting the digital library: bibliographic tools for the next generation web. PLoS computational biology 4(10), e1000204.

Michán-Aguirre L, Muñóz-Velasco I (2013) Cienciometr'`ia para Ciencias Médicas: Definiciones, aplicaciones y perspectivas.

Mouillot F, Field CB (2005) Fire history and the global carbon budget: a 1 \$ltimes $\$ 1$ fire history reconstruction for the 20th century. Global Change Biology 11(3), 398-420.

Pyne SJ (1995) "World fire: the culture of fire on earth." (Holt)

Song Y, Zhao T (2013) A bibliometric analysis of global forest ecology research during 2002-2011. SpringerPlus 2(1), 1-9.

Stork H, Astrin JJ (2014) Trends in Biodiversity Research-A Bibliometric Assessment. Open Journal of Ecology 4(07), 354.

Stull, R. 1988, An Introduction to Boundary Layer Meteorology, Kluwer Academic Press, Dordretch. The World Bank Group. 2014. http://data.worldbank.org/. Accessed 10/06/2014

Van Vliet N, Mertz O, Heinimann A, Langanke T, Pascual U, Schmook B, Adams C, Schmidt-Vogt D, Messerli P, Leisz S, others (2012) Trends, drivers and impacts of changes in swidden cultivation in tropical forest-agriculture frontiers: a global assessment. Global Environmental Change 22(2), 418-429.

Wildlife Conservation Society - WCS, and Center for International Earth Science Information Network - CIESIN - Columbia University. 2005. Last of the Wild Project, Version 2, 2005 (LWP2): Last of the Wild Dataset (Geographic). Palisades, NY: NASA Socioeconomic Data and Applications Center (SEDAC). http://dx.doi.org/10.7927/H4348H83. Accessed 10/06/2014.

Wilson CS (1999) Informetrics. Annual Review of Information Science and Technology (ARIST) 34, $107-247$.

Young R, Wolf S (2006) Goal attainment in urban ecology research: A bibliometric review 1975-2004. Urban Ecosystems 9(3), 179-193. 